\title{
KEY MANAGERIAL COMPETENCIES AND COMPETENCY MODELS IN INDUSTRIAL ENTERPRISES
}

\author{
KRAJCOVICOVA, K[atarina]; CAGANOVA, D[agmar] \& CAMBAL, M[ilos]
}

\begin{abstract}
The aim of this paper is to highlight the issue of managerial competencies and competency model in industrial enterprises. This paper builds upon the theory of knowledge processing and its role as a theoretical basis for knowledge development in the area of managerial competencies. Managerial competencies are becoming one of the key building blocks of success of the company to achieve both the mission and vision in creating added value and improve business performance and especially the development of their own people. A managerial competency is more than just knowledge and skills. It involves the ability to meet complex demands, by drawing on and mobilising psychosocial resources (including skills and attitudes) in a particular context. While skills and knowledge are a part of a manager's competency that can be measured fairly easily, intangible assets like effective communication and teamwork, while essential, are harder to pin down and evaluate. In the next parts of article is explained a concept of competency model. A competency model organizes the competencies needed to perform successfully in a particular work setting, such as a job, occupation or industry.

Keywords: managerial competency, degree of managerial competency, classification of managerial competencies, competency model
\end{abstract}

\section{INTRODUCTION}

Managerial competencies play today an important role in different types of organizations. The aim of enterprises is to move the performance of their employees still further and further. Competencies can detect the differences between average and excellent managers. Perhaps the potential power of an organization is to possess excellent or above average employees, through the elimination of average employees with continual education and the development of their personality. Although there are a lot of theoretical knowledge and concepts, the introduction of a competency approach is not quite a simple process. At first it means a change, with the aim of improving performance across the organization. And these facts require a change for each employees.

\section{DEFINITIONS OF MANAGERIAL COMPETENCE}

The issue of D. C. McClelland's article resulted in the realization of a large number of studies, created from a lot of studies about what is managerial competence. Moreover a lot of competency models were also developed. However, between the authors still remains a lack consensus in what is managerial competence and

what creates managerial competence. [1] among the experts in the field of management competencies there is not congruence in the understanding of this concept. The problem is the discrepancy in the expression of what the competence creates and what not.

Very often the concept of managerial competence links with the profession or with work activity. In particular, the meaning of the word used to refer powers to take decisions because of the power entails responsibility for the consequences of decisions taken.

A brief overview of the definition of managerial competencies

Perhaps CH. Woodruff defined this problem the best, when in his article: What is meant by a competency he claims that managerial competence is used as an umbrella under which everything fits, what may directly or indirectly relate to job performance. He defines it as "a set of employee behaviors that must be used for the position that the tasks arising from this position competently mastered." According to him, the competent manager must fulfill three basic conditions at the same time to fulfill their tasks. These are to:

1. possess the knowledge, skills and abilities, which are needed to this behavior,

2. be motivated to this behavior and be willing to spend the necessary energy,

3. have the possibility use this behavior in business environments. [1]

To understanding the concept of managerial competence and its the practical use, the best contribution is from R. E. Boyatzis, According to him managerial competence consists of two components, which are different from each other. One of them is a task that is necessary to fulfill and the second are the skills that workers must have to fulfill the role at the required level. In other words, we distinguish between what we do and what behavior is needed to fulfill the task in an excellent way.

S. Whiddett and S. Hollyford define managerial competencies as "sets of behaviors that enable individuals demonstrate the effective performance of tasks within the organization." [2]

N. Rankin says that "competencies are essentially the definition of expected performance, which should as a whole provide a complete picture of the most valuable 
behavior, values and roles required for the success of the organization." [3]

Other authors perceive the managerial competence as:

$>$ "any individual characteristic that can be measured or counted reliably and that can demonstrate significant distinction between effective and ineffective performance"

$>$ "basic skill and have facility needed for good work performance"

$>$ "all personal traits related to the work, knowledge, skills and values which encourage people to doing their job well". [3]

Many other writers focused their attention on managerial competence too. One of them is F. Hroník. He defines a managerial competence as a "bunch of knowledge, skills, experience and characteristic, which support the achievement of the objective." [4]

F. Krontorád and M. Trčka define the concept of managerial competence as "a combination of knowledge, skills, abilities and behaviors that an employee uses in carrying out their work and they are critical to achieving results which are consistent with the strategic goals of the organization. [5]

According to J. Lojda managerial competence is "the ability of the person (employee) to perform the job, to the required extent and desired quality of a particular job or activity." Managerial competencies also reflect the ability to flexibly react to the changing conditions. [6]

In life, we encounter situations where workers are not aware of their managerial competencies, however they take the view that they have these competencies, even if they do not.

The authors of this article argues that managerial competence perceive the ability, which effectively raises the characteristic behavior of the manager, whose results can be achieved above average performance for the manager position.

\section{DEGREE OF MANAGERIAL COMPETENCIES}

R.E. Boyatzis distinguished between threshold competency and differentiating competencies. Threshold competency refers to that minimum quality that a person needs in order to do a job such as the ability to speak the native language. Differentiating competencies refer to those factors that distinguish superior from average performers. Most threshold competencies are considered to be generic in nature in that they tend to apply to most managerial jobs whereas differentiating competencies may be more organization-specific. For instance, time and again, the list of basic management competencies has included analysis, communication, creativity, decisionmaking, etc. However, a competency such as awareness of international ways of approaching business deals may be a critical factor determining job success and high performance in a particular global company "Fig.1". $[1,7]$

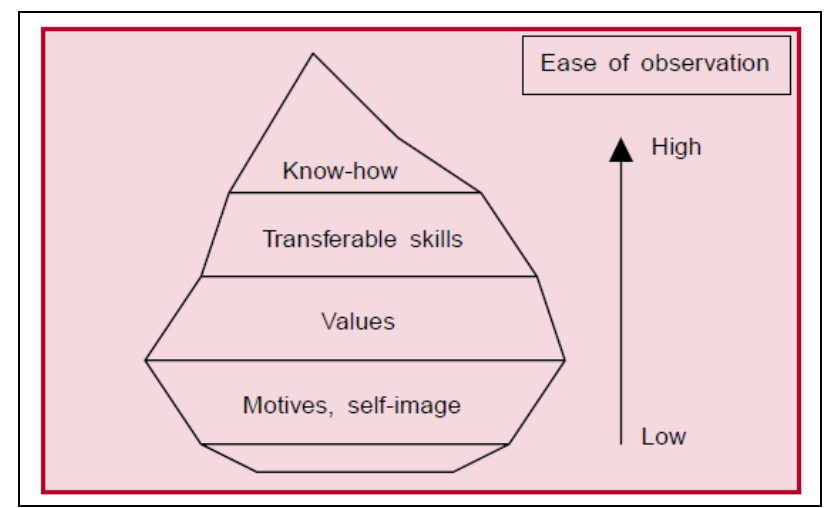

Fig. 1. Iceberg model

\section{CLASSIFICATION OF MANAGERIAL COMPETENCIES}

As with the definitions and components of managerial competencies, as well as their classification among the authors is lacking consensus. The most frequently reported breakdown of managerial competencies, according to several authors, publications division is as follows:

1) threshold - the basic skills and knowledge required to perform work, without which the employee unable to perform specified work. In this case, we can not distinguish the excellent workers from the average employee,

2) performance (divergent) - commitment to achieving high performance. Their aim is to emphasize the difference between excellent, above average and average workers. [1]

According to our opinion, if you correctly identify the requirements and development needs of employees and then set the appropriate educational projects, it can bring an increase of performance for the employees. Increasing efficiency can highlight differences between excellent, above average and average workers.

In this paper we classify management competencies into three groups: general, specific and key (crucial). The main criterion of our division of managerial competencies is above average managerial performance . Within the company HayGroup, the performance is defined as "any behavior which exceeds the average performance of the group at least one standard deviation value."

$\square$ General managerial competencies, which every manager should have, are able to give quality work performance in any management position.

- Specific management competencies will include the managerial competencies, which are needed to fulfill the standard performance for a particular management position.

- Key management competencies are those which the manager gives increased importance to and which enhance employee performance. 


\section{THE FOUR PILLARS OF MANAGERIAL COMPETENCIES}

If you are playing a management role in your organization, or plan to be in a managerial position, it is important for you to learn about the 4 Pillars of Managerial Competencies.

The 4 pillars don't stand independent of each other, but form a unified whole. They are:

- Knowing the Organization

- Leading and Managing People

- Managing Resources

- Communicating Effectively

Knowing the Organization involves developing knowledge and understanding of current policies and operating procedures to ensure that unit activities are effective and aligned with the larger goals of the organization. This pillar includes competencies related to policies, procedures, vision, mission, goals, strategic plan, etc.

Leading and Managing People entails developing skill in providing feedback and direction for staff, assuring the satisfaction of customers, and creating a collaborative environment that encourages initiative and problem-solving. Within this pillar are skills related to performance evaluation, staff development, team building, collaboration, customer relations, etc.

Managing Resources concerns understanding the tools and processes for planning to meet specific goals and place efforts in the larger context of strategic initiatives. This pillar includes skills in planning, project $\&$ budget management, information management, change management, organizational performance assessment, etc.

Communicating Effectively includes building skills to foster smooth and satisfying interactions among staff and with customers. The competencies include managing meetings, listening, constructive feedback, effective presentation, written communication, etc. [3]

\section{COMPETENCY MODELS}

The result of the identification of managerial competencies is to create a competency model. A competency model is a collection of competencies that together define successful performance in a particular work setting. The existence of competency models to facilitate the work of recruiting in the design of training and development activities. It becomes the basis for the evaluation of job performance and direction in career planning. This list of managerial competencies in a competency model for management of the company suddenly become a big surprise. Its task is to detect differences between what the company declares, what they expects from its people, and between what they required. Competency models can be developed for specific jobs, job groups, organizations, occupations or industries. [1,7]
A competency model describes a specific combination of knowledge, skills and other personality characteristics. They are necessary for the efficient execution of tasks in the organization.

There are several types of competency models. Therefore, in the development of competency model depends primarily on the intentions and direction of the company. The competencies in a model may be organized in a variety of formats. No one approach is inherently best. Rather, organizational needs will determine the optimal framework. A common approach is to identify several "core" or "key" competencies that are essential for all employees, and then identify several additional categories of competencies that apply only to specific subgroups. Some competency models are organized according to the type of competency, such as leadership, personal effectiveness, or technical capacity. Other models may employ a framework based on job level, with a basic set of competencies for a given job family and additional competencies added cumulatively for each higher job level within the job family.

\section{Procedure for establishing competency model}

When creating competency models work we can simplify this procedure:

\section{Set the precise objectives of the project}

Before the company proceeds to create competency model, you must make clear goal that follows the creation of competency model. The reasons for the application of competency models can be more.

\section{Defining the scope of the project and the target group}

As soon as we find a key motive for the application of the competency model of organization is not difficult to identify which groups of workers will be affected. Good competency model includes specific behaviors, illustrating a good level of development of each competency. It is necessary that such descriptions exist for each group. That is why the model can become very large, and especially difficult to create.

\section{Choose an approach}

The simplest is to use the baseline situation of existing competency model. Much more difficult is the process of modifying or creating a completely new model. Next steps will involve creating a new competency model.

\section{Assemble project team}

In project team in creating a competency model should not miss the key managers of the department to which the model will be directly affected. The main task of the project team is to determine the detailed parameters of output and how to implement with measurable success criteria. Indispensable tool in the work of the project team's action plan for the project, which helps to estimate the demand for team members to create a budget assumptions for successful implementation.

\section{Identify the different levels of performance at a given position}


It is necessary to define the criteria for effective performance. Only by being able to identify workers who make above average, average or below average performance.

\section{Collect and analyze data}

This phase is the creation of the model itself. The result is a preliminary competency model.

\section{Verify competency model}

Upon completion of the competence model is correct, so that we verified. Thus, virtually by checking whether a behavior model described which makes managers deliver outstanding results. This phase is extremely important and can also be very difficult.

\section{Prepare a competency model for use}

Implementation of the competency model is usually easier if future users were included in the project team. [1]

\section{CONCLUSION}

Managerial competencies provide a very valuable addition and enhancement to the typical performance management process, with benefits for both the employee and the organization.

$\square$ For employees, the assessment provides information on how their competencies support and contribute to the organization's success as well as a framework for planning learning and development in their current role and also for their advancement within the organization.

For the organization, the assessment of competencies can provide valuable insights on the skills and talent pool resident within the organization, as well as the competency gaps that need to be addressed to meet both current and future needs.

So, why are some people more successful than others? The answer is partially a function of the individual and partially a function of how they fit in a particular role.

As McClelland showed, it is necessary to look beyond basic skills and knowledge required to perform an adequate job and into the deeply rooted competencies - an individual's social role, self-image, traits, and motives - that can most accurately determine highpotential candidates. In addition, an individual's competencies must fit, or be able to fit through development, those required to achieve outstanding performance in a job. [1]

When organizations make the effort to apply competencies to select and develop individuals for key roles, they avoid the collateral damage-recruiting costs, low morale, dissatisfied customers, missed opportunities - associated with a bad hire.

And, most importantly, they greatly increase the odds that selected individuals will perform at a very high level and help drive the success of the company.

The article was prepared in the framework of scientific research project VEGA no. 1/0787/12: The identification of sustainable performance key parameters in industrial enterprises within multicultural environment

\section{REFERENCES}

[1] KUBEŠ, M., SPILlEROVÁ, D., KURNICKÝ, R. (2004). Manažerské kompetence: Způsobilosti výjimečných manažerů, 1 . vyd. Grada Publishing, ISBN 80-247-0698-9., Praha

[2] WHIDDETT, S. - HOLLYFORDE, S.( 2003). A practical guide to competencies: How to ennce individual and organizational performance, CIPD, ISBN: 1-84398-012-6, London

[3] ARMSTRONG,M. - STEPHENS,T.( 2008). Management a Leadership, Grada Publishing, ISBN 978-80-247-2177-4, Praha

[4] HRONÍK, F. (2007). Rozvoj a vzdělávání pracovníků, Grada Publishing, ISBN: 80-247-1457-4, Praha

[5] KRONTORÁD, F. - TRČKA, M. (2005). Manažérske standardy ve veřejné správě.: Národní informační středisko pro podporu jakosti, ISBN: 80-02-01769-2, Praha

[6] LOJDA, J., (2011). Manažérske dovednosti. Grada Publishing, , ISBN: 978-80-247-3902-1, Praha

[7] BOYATZIS, R. E.( 1982). The competent manager: a model for effective performance.,Wiley, ISBN: 0-471-09031-x, New York

[8] Tureckiová, M.( 2004). Ř́zení a rozvoj lidí ve firmách, Grada Publishing, ISBN 80-247-0405-6, Praha 